\title{
Research of Thermoelectric Enterprise Marketing Management Information System Integration Model
}

\author{
Zhigang $\mathrm{Li}^{1,2,3}$ \\ 1. College of Economics \& Management, China \\ Agricultural University, Beijing ,100083, China \\ 2. Xinjiang TianFu Thermoelectric CO., LTD, Shihezi City, \\ 832000, Xinjiang, China \\ 3. Collage of Information Science and Technology, Shihezi \\ University, Shihezi City, 832000,Xinjiang, China
}

\begin{abstract}
Domestic power marketing system means more backward, and the marketing organization system is imperfect. Due to business expansion and increased market competition, Tianfu thermoelectric original electric gas marketing system can no longer meet the needs of enterprise development which lead to information islands. According to the current operating status of the joint stock company and existing problems, this paper study a large marketing integration model, and constructed a marketing network management system platform integrated with electricity, heat and gas for the thermal power enterprises. the establishment of an integrated marketing platform with electricity, heat and gas business is built on a unified infrastructure platform in order to unify customer information, marketing basic platform capabilities and customer service platform function, centralize management of electricity, heat, gas marketing business in one of a big marketing intensive management mode including electricity, heat and gas.
\end{abstract}

Keywords-Marketing Model; Marketing Information System; Integration

\section{INTRODUCTION}

\section{A. Development status at home and abroad}

The State Grid Corporation proposed the "SG186 Project" plan of system-wide implementation in April 29, 2006. According to the plan, "SG186 Project" will achieve four goals: the first one is to build "longitudinal through, transverse integration" platform, to achieve information and data sharing in companies; the second one is to build eight business applications to adapt to the company's management needs and improve the ability of management of business in the company; the third one is to establish and perfect six information guarantee systems, to promote the rapid, healthy and sustainable development of informatization; and the last one is to the goal of be domestic and international advanced by the end of "eleventh five-year plan", initially set up digital power grid and informationization enterprise[1].

At present, power marketing in the United States, Europe, Japan and other developed countries has entered the era of intelligent and networked. The traditional marketing content of recording, counting and charging, has changed to a new work system of customer-centered, purpose-promoting and service-aim[2][3]. Looked from the overall, developed foreign power supply enterprise in the electric power market after deregulation pay more attention to intelligence

\author{
Zetian $\mathrm{Fu}^{1}$ \\ 1. College of Economics \& Management, China \\ Agricultural University, Beijing ,100083, China \\ Jiayong $\mathrm{He}^{2}$ \\ 2. Xinjiang TianFu Thermoelectric CO., LTD, Shihezi City, \\ 832000, Xinjiang, China \\ E-mail:lzg_inf@shzu.edu.cn
}

technology and equipment adopted, improve the reliability and quality of power supply, more ability to focus on customer service, make full use of automatic meter reading, intelligent ammeter, network technology, call center technology and Internet technology, make the response service faster and better[4].

The status of domestic electricity marketing: Firse,Reform and adjust marketing institution. At present, the reform and adjustment are moving to adapt to the development of market economy and the direction of the new situation of the electricity buyer's market. Second, Adoption of new technical means. With the rapid development of computer and network communication technology, the new technology used in power marketing is growing. Thirdly, A large amount power customer service center emerges. The establishment of the customer service center makes the electric power enterprises more standardized and modernized for customer services[5][6][7].

\section{B. Problems in domestic power marketing}

- Backward in technology.

- Imperfect marketing organization system.

- Information coding unrealized standardization.

- Low quality of personnel cannot satisfy the needs of modern marketing.

C. The current situation of the development of information in Xinjiang Tianfu Thermoelectric Co., LTD.

Xinjiang Tianfu Thermoelectric Company was mainly engaged in the production and supply of electricity, heat and gas. The company is the only one in Xinjiang co-generation, combined heat and power generation, Fire and water electricity, generate ,offer, adjustable integrated electric energy enterprise.

After the continuous information construction in the past few years, has built a power marketing management information systems, the rural power marketing management information systems, heating marketing management information systems and a number of excellent marketing information system, for marketing services provide excellent information technology support. But we also see that there are a lot of inadequacies. Mainly include: The market competition intensifies; The original marketing information system can't meet the development needs of the enterprise; 
The lack of top-down whole informatization construction planning; IC card is not uniform.

According to the company current existing problems, it is necessary to establish an integrated big marketing platform, electricity, heat, gas business is built on a unified platform, unified customer information, and unified management, to provide customers with one-stop service, enhance the core competitiveness of enterprises, improve the capacity and quality of customer service.

\section{SOA-ORIENTED PLATFORM ARCHITECTURE}

Service-Oriented Architecture (SOA) is a component model. Using open standard makes the different functional units of application (known as Service) through the interfaces and the bonds linked together, the key is to realize the business application integration and components reuse by other system [8] [9].

In the study of electricity, heat, gas marketing and management information system on the basis of the actual demand in open, standard, integrated. To research based on SOA integration of marketing and management information systems. Utilized the business components, services and applications layered design idea, studies on electrical, heat, gas marketing system involving key technology such as the Java EE technology, XML technology, Web application framework, workflow service, rights management services, integration services, gallery electric gas fee calculation service, charging management services, statements of management services and so on. As shown in Figure 1.

\section{INTEGRATION MARKETING MANAGEMENT INFORMATION SYSTEM PLATFORM}

\section{A. The existing marketing system application}

The existed marketing system has the basic electricity, heat, gas of business transaction, cost management, query and limited marketing report function, the system according to the specific business independent construction, mainly to meet the customer's electricity, heat, gas business can deal with and billing, payment demand. shown in Figure 2.

\section{B. Business Processes of Integrated Marketing Information System Platform}

Marketing and management information systems business process is shown in Figure 2.Include:Business expansion process design; Charge fees business process analysis, Analysis of the measurement business process.

\section{Design of Integrated Marketing Information System}

\section{1)System design research methods}

- According to the electricity, heat, gas market information, business information is different, classification, integrated design.

- Establish the appropriate options for different type of customer, the type of service and the type of management, development and design the corresponding functional options, automatic user the type recognition technology, the development of a data acquisition system.
- Technically using SOA, J2EE three-tier B/A/S architecture, data warehouse technology.

2)The basic content of the system design

- Analysis and design of SOA.

- Building J2EE three-tier B/A /S architecture/.

- Design of the data warehouse system.

3)System function framework

System function framework shown in Figure 6.

The integration integrated marketing information system platform followed the architecture design and technical standards of the State Grid Corporation SG186 engineering. Refering to the successful experience of SG186 engineering, according to their own management characteristics and the drawback of marketing system, Tianfu Thermoelectric Co. puts forward the integrated big marketing information system platform design thought.[10].

Through constructing integrated big marketing information system platform, to realize information longitudinal through, transverse integration, and support collectivize operation; Construct headquarters, branch offices unified data center, shared data resources, promote intensive development; deploy three layer applications of corporation and branches, optimize business process, and realize meticulous management. We can provide a unified and standard electricity, heat, gas one-stop service, and realization electricity, heat, gas "one-stop charges, a card will be charged".

4)The main function of the marketing system

- Establish enterprise data center, centralized storage of the business system data. The data of the stock company, such as the power supply, heat supply and gas supply enterprise unified data stored in the data center.

- Establish enterprise portal system, to achieve a single sign-on. Integrated information platform, can greatly improve the system performance, reduce misuse operation, We can reduced the customer's business processing time to minimum, improve service quality[11].

- Establish power energy information collection and management system of the power purchase, supply and sale departments. Integrated system of electric power sale each link power integrated information acquisition, monitoring, integration and comprehensive application, for the integration of marketing information system to provide the basic data for the user of power grid enterprises..

- Establish electricity, heat, gas IC card "all-in-one-card" system. It is necessary to build unified electricity, heat, gas IC card application platform, to achieve "a multi-purpose card", completely solve the compatibility problems of the smart card, to minimize the difficulty of enterprise management, the user simply a card to pay electricity, heat, and natural gas business.

- Create a marketing analysis and strategic decision-making system.Marketing analysis and auxiliary decision system based on "the data 
concentration, applied concentrated" integrated marketing information system platform as the foundation, construction group data center in the high-end application to electricity, heat, gas and so on various subordinate enterprise marketing related business data as the foundation, relying on the subordinate enterprise database, construct marketing auxiliary decision analysis center data warehouse, realize on-line auxiliary decision analytical processing.

\section{CONCLUSION}

The system uses SOA, J2EE three-tier B / A / S system and the data warehouse technology. According to the latest electric, gas, fuel gas and other individual marketing management system research, application of SOA framework system, fast and efficient, time-saving and labor-saving, low integration of enterprise information system single, meet the strategic goal of the enterprise demand, construction has the core competitiveness of the enterprise information system.

\section{ACKNOWLEDGMENT}

This project was supported by Postdoctoral Funded Projects Fund: Research of Electricity, Heat, Gas Smart IC card Platform Marketing Management Information System of Xinjiang TianFu Thermoelectric CO., LTD.

\section{REFERENCES}

[1]. State Grid Corporation of China<Marketing and management of business applications overall construction program>2006,6.
[2]. XU Weiting,LIU Junyong,LIU Youbo,HU Can.Summary of research on intelligent sales and marketing of smart grid (1): current situation of relevant research abroad and revelation[J]. Electric Power Automation Equipment. Feb. 2010.Vol. 30 No. 2:139-144

[3]. Nie Yun Shen, He Xue Ming. France, Japan, the United States electric power marketing mode overview. State Grid.2007.8

[4]. Hong Tao. The business design of the marketing technical support system of the Shan dong Electric Power[D]. North China Electric Power University(He Bei),2008

[5]. Shandong Electric Power Group Corporation.County-powered corporate power marketing technical support system functional technical specifications[S].2006.

[6]. Qiu Xianhui.The construction of the power marketing system[J].Guangxi Electric,2007,4.

[7]. Wang Fei,Lu Jianjun,Zheng Wenyan.Research and Application of Struts in J2EE Web layer[M].Modern electronic technology,2006,29(18):68-70.

[8]. Panagiotis Louridas.SOAP and Web Services[J].Software,IEEE,2006,23(6).

[9]. Huan Changwu,Li Rui,Wang Jianlin.Design and Implementation of the power marketing system based on J2EE technology and SOA architecture[J].Computer and Information Technology,2006,11.

[10]. Jin Xin. Research and Application of the Management Information System of Electric Power Marketing[D]. North China Electric Power University(Beijing), 2007

[11]. HUANG Zu-you. Design Analysis of J2EE-based Management Information System for Power Marketing[J].Guang Dong Electric Power.2009.Vol.22,No.9

\begin{tabular}{|c|c|c|c|c|c|c|c|}
\hline Presentation layer & \multicolumn{7}{|c|}{ Industry expanding, measurement, dosage fees, charges, inspection, etc. Used in each module interface display } \\
\hline Business Logic Layer & \multicolumn{7}{|c|}{ Realization of business logic (business components, services), external interface, service calls, etc. } \\
\hline $\begin{array}{l}\text { Application } \\
\text { services layer }\end{array}$ & $\begin{array}{c}\text { Web } \\
\text { application } \\
\text { framework }\end{array}$ & $\begin{array}{l}\text { Workflow } \\
\text { Services }\end{array}$ & $\begin{array}{c}\text { Rights } \\
\text { Management } \\
\text { Services }\end{array}$ & $\begin{array}{c}\text { The } \\
\text { Gallery } \\
\text { integration } \\
\text { of service }\end{array}$ & $\begin{array}{c}\text { Cost } \\
\text { computing } \\
\text { services }\end{array}$ & $\begin{array}{c}\text { Fee management } \\
\text { services }\end{array}$ & $\begin{array}{c}\text { Report management } \\
\text { services }\end{array}$ \\
\hline Persistence layer & \multicolumn{7}{|c|}{ Data access, data objects } \\
\hline $\begin{array}{l}\text { J2EE infrastructure } \\
\text { services layer }\end{array}$ & \multicolumn{7}{|c|}{ Enterprise Application Server: J2EE API (such as JNDI, JDBC, JTA, JMS, etc.) } \\
\hline System resources layer & \multicolumn{7}{|c|}{ Database management systems, network protocols, operating systems } \\
\hline
\end{tabular}

Figure 1. Platform Architecture Figure 


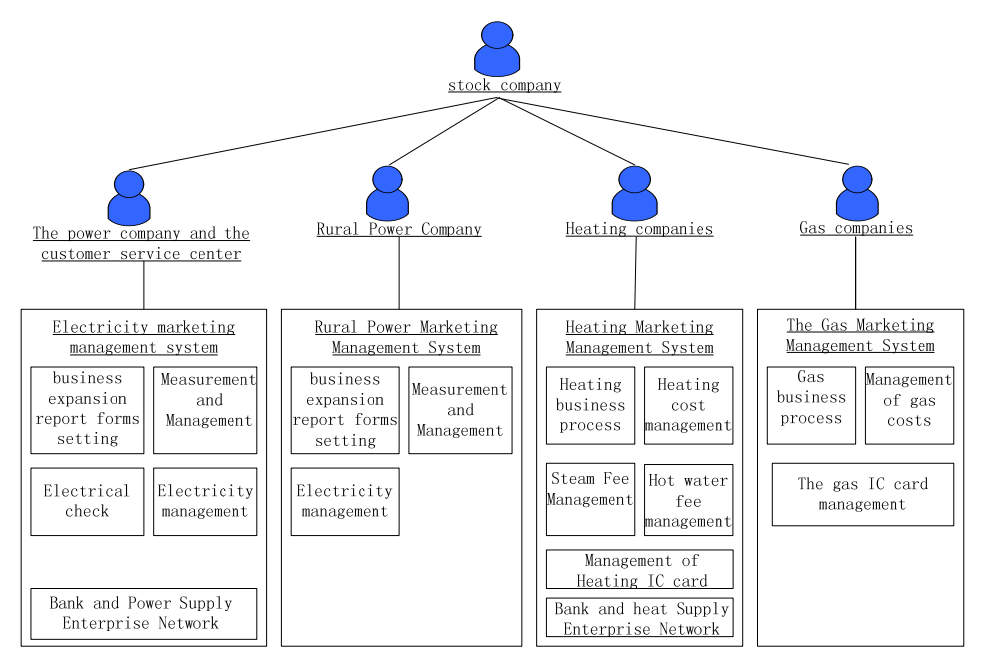

Figure 2 Chart of the existing marketing system application

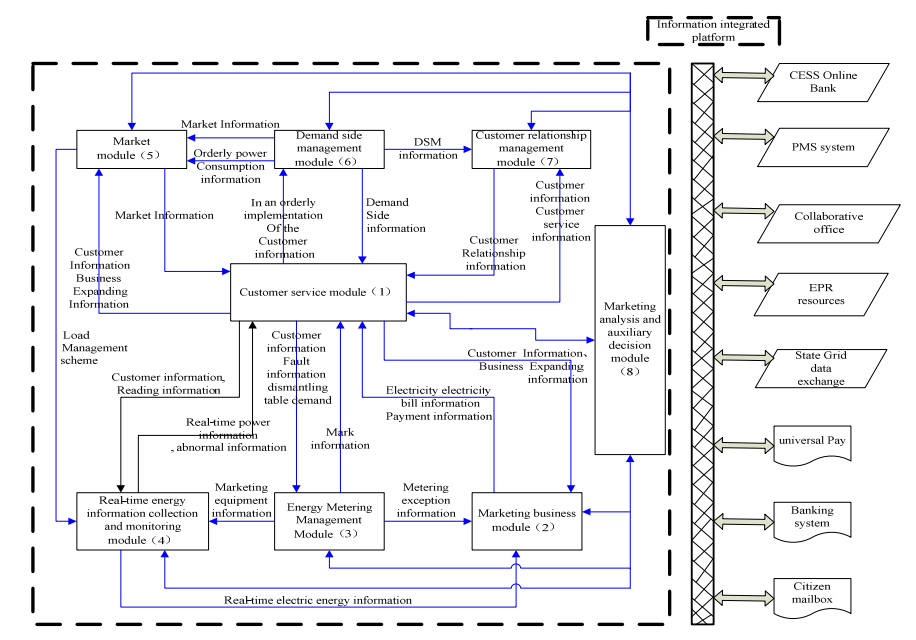

Figure 3. Marketing and management information systems business processes

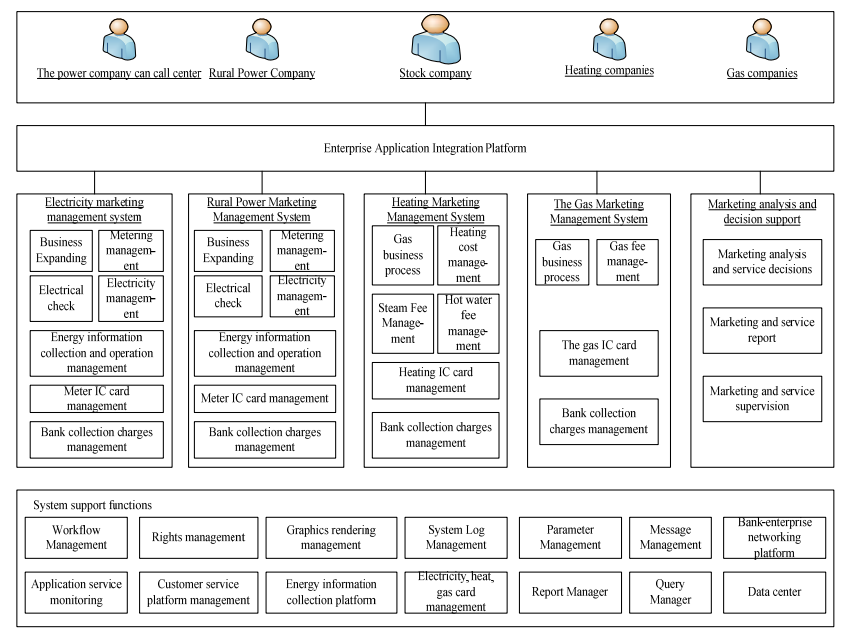

Figure 4. Enterprise Integration Application Platform 